\title{
Online course on advanced life support in cardiorespiratory arrest: innovation for continuing education
}

\author{
Curso on-line sobre suporte avançado de vida em parada cardiorrespiratória: inovação para \\ educação permanente
}

Edenir Aparecida Sartorelli Tomazini ${ }^{1}$, Lucia Tobase ${ }^{1}$, Simone Valentim Teodoro ${ }^{1}$, Heloísa Helena Ciqueto Peres ${ }^{2}$, Denise Maria de Almeida², Débora Cristina Alavarce²

\begin{abstract}
Objective: to build and validate an online course for nurses on advanced life support in adult cardiorespiratory arrest. Methods: methodological research, technological production, based on Contextualized Instructional Design, following the phases of analysis, design, development, implementation and evaluation, guided by the assumptions of Andragogy and Theory of Significant Learning. Results: course structured in nine learning units, including digital games, virtual simulations and clinical cases. It was made available in the Moodle ${ }^{\circledR}$ virtual environment and evaluated by 16 specialist nurses, obtaining high and good quality indexes in 15 (75.0\%) criteria regarding content, interactivity, navigation, ergonomics and aesthetics. Conclusion: the positive evaluation of specialists accredits the online course on advanced life support in adult cardiorespiratory arrest as a valid resource capable of integrating innovative educational technologies and strategies to nurses for care in cardiopulmonary resuscitation.
\end{abstract}

Descriptors: Educational Technology; Education, Distance; Heart Arrest; Education, Continuing; Nursing Informatics.

Objetivo: construir e validar curso on-line para enfermeiros sobre suporte avançado de vida na parada cardiorrespiratória em adultos. Métodos: pesquisa metodológica, de produção tecnológica, fundamentada no Design Instrucional Contextualizado, seguindo as fases de análise, design, desenvolvimento, implementação e avaliação, norteada pelos pressupostos da Andragogia e Teoria da Aprendizagem Significativa. Resultados: curso estruturado em nove unidades de aprendizagem, incluindo jogos digitais, simulações virtuais e casos clínicos. Foi disponibilizado no ambiente virtual Moodle ${ }^{\circledR}$ e avaliado por 16 enfermeiros especialistas, obtendo índices de alta e boa qualidade em $15(75,0 \%)$ critérios referentes ao conteúdo, à interatividade, navegação, ergonomia e estética. Conclusão: a avaliação positiva de especialistas credencia o curso on-line sobre suporte avançado de vida na parada cardiorrespiratória em adultos como recurso válido, capaz de integrar tecnologias e estratégias educacionais inovadoras a enfermeiros para atendimento na reanimação cardiopulmonar.

Descritores: Tecnologia Educacional; Educação à Distância; Parada Cardíaca; Educação Continuada; Informática em Enfermagem.

\footnotetext{
${ }^{1}$ Secretaria Municipal de Saúde, Serviço de Atendimento Móvel de Urgência. São Paulo, SP, Braszil.

${ }^{2}$ Universidade de São Paulo, Escola de Enfermagem de São Paulo. São Paulo, SP, Brazil. 


\section{Introduction}

In the health area, due to the constant transformation of information and technological resources, linked to the need to ensure quality assistance to users, it is imperative to continuingly search for knowledge, where discussion and reflection on teaching processes are required and learning necessary for work training. Thus, continuing health education represents an important strategy in the training of health service workers throughout life, and allows adding skills to qualify care practices, in addition to the technical dimension, seeking to respond to the health needs of the population, for new forms of organization and integration of work processes and vocational training ${ }^{(1)}$.

In this education, it is inherent to associate technology in the restructuring of the teaching and learning process, which allows access to information and new digital media, according to the globalized cultu$\mathrm{re}^{(2)}$. Technological tools, mediated by the computer and internet use, in the development of educational actions, including in a virtual learning environment, contribute to the dissemination of content and the promotion of learning, with temporal flexibility ${ }^{(3)}$. Virtual learning environments are multimedia spaces on the internet, analogous to the classroom in person. They allow to expand access to education, integrate different virtual media and learning objects, making the educational environment dynamic, multisensory, flexible, closer to the reality of the user ${ }^{(4)}$.

Understandable as educational resources, learning objects are able to convey information in various formats and languages, such as illustrations, still images, videos, audios, texts, hypertexts, web pages, games, interactive exercises and simulations, to aid teaching and learning as well as stimulating the development of personal capacities, such as reasoning, creativity and decision-making(5). These aspects are important in the construction of nurses' competencies, including in emergency situations, such as in cardiorespiratory arrest care.
Cardiopulmonary arrest consists of an emergency of high complexity and requires the quick and accurate actuation of nursing professionals, as well as the need to organize and standardize actions in the face of frequent updates and changes that occur in the American Heart Association guidelines and institutional protocols ${ }^{(6-7)}$. Nurses are part of the nursing team, and are often the first professionals to encounter cardiac arrest, therefore, as team leaders, they need to master scientific knowledge and the technical skills to act efficiently and quickly in resuscitation cardiopulmonary, in performing basic and advanced life support maneuvers, in addition to educational actions ${ }^{(8)}$.

In this perspective, it is understood that lifelong education proposes to the professional the development of a conscious and responsible practice, based on self-knowledge, improvement and updating, which promote the increase of personal and professional competence and appreciation, as well as the contribution to improvement of the assistance provided to the client, the community and the institutions in which they operate ${ }^{(8)}$. It is therefore necessary to adopt new practices, the development and use of technological resources as strategies for learning to be productive and enjoyable, but without losing sight of the main goal of dissemination of knowledge.

In this way, the evolution of technology and the web provide new ways of conducting nursing education and enables new spaces of interaction, communication and teaching and learning conception ${ }^{(4)}$, in the updating and qualification of nurses in advanced life support in cardiopulmonary arrest in adults.

In this context, this research aimed to build and validate an online course for nurses on advanced life support in cardiorespiratory arrest in adults.

\section{Methods}

Methodological research, technological production ${ }^{(9)}$ concerning the development and evaluation of online course for nurses on advanced life support in cardiorespiratory arrest in adults. It was held from 
March to November 2016, at the University of São Paulo School of Nursing.

In the construction of the course in the virtual learning environment, the contextualized instructional design model was used, from the analysis, design, development, implementation and evaluation pha$\operatorname{ses}^{(9)}$.

In the analysis phase, it was characterized the target audience, defined the topic and the bibliographic reference, carried out the analysis of the technological infrastructure for development, implementation and maintenance of the course. In the virtual educational proposal on advanced life support in cardiorespiratory arrest in adults, the nurses were listed as a target audience for self-instructional training in continuing education programs.

In the design, the instructional matrix was defined, according to the planning of the pedagogical conception, the learning units, the educational objectives and the contents, as well as the selection of the media (texts, images and videos), the strategies of evaluation of learning and interface, and defined the navigation structure.

The course was designed in nine learning units that address the interventions of the cardiorespiratory arrest response algorithm in adults, guided by the American Heart Association guidelines and the guidelines of the Brazilian Society of Cardiology ${ }^{(6-7,10)}$. Educational objectives were elaborated based on Bloom's Taxonomy ${ }^{(11)}$. The educational principles that guided the structuring of the course, the production of media and didactic materials were based on Knowles, on the andragogy assumptions ${ }^{(12)}$ related to adult learning, and on the Ausubel Significant Learning Theory ${ }^{(13)}$. The construction of storyboards, through PowerPoint ${ }^{\circledR}$ and Word $\AA$, favored the definition in the sequence of contents and implementation in the virtual learning environment.

In the development, materials such as contents and learning objects (images and interactive exercises) that make up the evaluation strategies, as well as the tutorial and navigation route were made. Par- tnerships enabled the creation of didactic material with resources of the virtual man, next to the area of telemedicine from the School of Medicine of the University of São Paulo, Brazil; the production of illustrations, games and simulation, as well as the structuring of content in the virtual learning environment, using the Moodle ${ }^{\circledR}$ lesson feature, developed by a company specialized in the production of educational resources, after being outlined in storyboard by the researcher.

The content of the media and didactic material was elaborated by the researcher and reviewed by three other nurses who work in emergency, with experience in urgency and emergency, continuing education and distance education.

The implementation phase involved the configuration of the tools and resources in the Moodle ${ }^{\circledR}$ 3.1 virtual learning environment for access through different browsers and technological devices. The provision of login and password to the evaluators was foreseen for access to the course and, later, to the target public.

The process of learning evaluation was delineated in the diagnostic dimensions, carried out at the beginning of the course, with specific questions of each learning unit; through exercises with feedback and digital games throughout the course; in the end, with final test in the virtual simulation format to evaluate the participant's performance in the decision making regarding the priority interventions of advanced life support in the attendance to cardiorespiratory arrest.

In the last phase, evaluation of the online course was carried out by sixteen experts in urgency and emergency to the adult and or online education, with a minimum of two years' performance, aiming to verify the aspects related to the content and the interface of the virtual environment. The selection of the evaluators was random, intentional and non-probabilistic. According to International Organization for Standardization and International Electrotechnical Commission (IOS/IEC) 14598-6, at least eight participants in each category of evaluators are recommended ${ }^{(14)}$.

To evaluate the course, the "tool for evaluating 
the quality of learning objects from the user's perspective", version 5.0 was used ${ }^{(15)}$. The obtained data were compiled in Excel ${ }^{\circledR}$ spreadsheets, submitted to the statistical analysis, through the software Statistical Package for the Social Sciences, version 22.

The research was carried out with approval by the Research Ethics Committee of the Nursing School of the University of São Paulo, in a consolidated opinion no 1,667,269/2016 and CAAE identifier $54831516,5,0000,5392$. After agreement of the participation, through an Informed Consent Term, sent in digital format, the instrument for the evaluation of the course was made available.

\section{Results}

In the present study, the main results were organized in relation to the development and evaluation of the online course. In terms of development, the course was configured with an estimated workload of 36 hours and made available on the Moodle $₫ 3.1$ platform, at http://gepete.com.br/login/index.php, with access by means of login, on the identification screen. The course design was drawn from the instructional design matrix in nine defined learning units, according to the algorithm of advanced life support in adult care in cardiorespiratory arrest, including specific educational objectives, contents, learning objects, strategies pedagogical and evaluation criteria.

In the initial screen, icons for access were provided to the tutorial, diagnostic evaluation, course plan, doubts and certificate, which present essential information for the study of the participant. In the tutorial the guidelines on the commands and the functioning of the icons were presented, as well as the general educational objective of the course, the strategies of evaluation of the learning and the route of navigation to illustrate the paths taken by the participant during the learning process by the units of study.

In order to begin the course, the participant should carry out the activity called "diagnostic evaluation", through a questionnaire consisting of 36 questions, four of them for each topic, addressed in the nine learning units that have the purpose of identifying knowledge gaps of the participant and which topics need to be reviewed in full or in parts, and thus guide the paths to be covered during the studies. On the "course plan" screen, icons were also available for access in case of doubts, certificate, library, media library, glossary, final simulation, full course and diagnostic evaluation, in case the participant should want to repeat it.

The icon "doubts" consisted of the communication way with the teacher and the participant. The "library" and the "media library" provided supporting and complementary teaching materials to expand the knowledge, such as the national and international guidelines for cardiorespiratory arrest care, scientific articles, info graphic on basic life support and supporting texts on the themes, links to web pages and videos, with free access and download. The glossary, with the definition of terms, aimed to help in the definition of concepts and contents. The "certificate" can be accessed upon completion of the course.

The learning units were structured using the "lesson" feature of Moodle $®$, adopting hypertexts, videos, learning exercises and digital games. Hypertexts allow access to other content, pages or learning units in a flexible, dynamic and non-sequential way. To support learning, videos on electrocardiogram, airway opening, oral pharyngeal cannula insertion and laryngeal mask, oral tracheal intubation, use of the automatic external defibrillator and synthesis of basic life support maneuvers were made available.

The learning exercises, as part of the formative evaluation, were structured through questions with immediate feedback for each alternative. Digital games, inspired by the classic "Space Invaders", and puzzle integrated the formative assessment by presenting a brief synthesis of the content addressed in each unit of learning. In the "summative evaluation", virtual simulation was used, composed of clinical cases representing the patient's conditions in cardiorespiratory arrest and the maneuvers of advanced life 
support, aiming to bring the participant closer to real situations.

Regarding the evaluation, the on-line course was evaluated by sixteen specialists, total training nurses, eight with experience in urgency and emergency and eight in online education, predominantly female ( $81.3 \%$ ), average age of $43 \pm 7.77$ years. The average time of professional training was $18.62 \pm 7.43$ years and the experience time was $14.87 \pm 6.08$ years. In relation to the highest degree, seven (43.8\%) completed specialization, five (31.3\%) master's degree and four $(25.0 \%)$ doctorates.

The evaluators considered the course of discharge and good quality in $15(75.0 \%)$ criteria regarding pertinence, contextualization, information quality, navigation, references, portability, content correction, information clarity, ease of interaction learning and information localization, interactivity, efficiency of use, use of audiovisual resources, ergonomics and aesthetics; and medium quality in five (25.0\%) attributes related to the virtual environment, such as ease of return, use of special brands, error management, multiple windows, help to users, being considered adequate to be used in the training and updating of nurses. The theoretical-methodological and pedagogical frameworks adopted were positively evaluated, as they enabled the integration of innovative educational technologies and strategies.

The improvements suggested by the evaluators were carried out, these consisted of reviewing the evaluation questions and the concepts that were complex; expanding the use of hyperlinks and icons to reduce the informational and resource load that would allow multiple windows to be opened simultaneously; standardization of colors and positioning of icons; menu availability on all screens; and enabling other resources to assist the user.

\section{Discussion}

The limitation of this research refers to the stages reached so far, in relation to the partial results obtained in the development and evaluation of the online course, once the application of this to nurses and the evaluation of learning of the students, in the next stage, later in the continuation of the research. Learning objects, such as games and virtual simulation, were created by a company specialized in the production of educational resources, which is why they were not submitted to validation.

Project implementation, such as training in advanced life support in adult cardiorespiratory arrest, is highlighted in the American Heart Association guidelines for optimizing quality patient care, which significantly influences resuscitation success and increased survival ${ }^{(6,16)}$. According to these guidelines, there is increasing evidence that recertification in basic and advanced life support every two years is insufficient for most people, and although there is no ideal time frame for the study period and exposure to the contents and improvements in skills and confidence among professionals receiving training more frequently ${ }^{(6)}$.

From this perspective, the online course addresses theoretical aspects about the interventions listed in the algorithm on advanced life support. In order to guide the course design, the educational objectives were defined, according to the recommendations of the learning theories, focusing on the adult participant, motivated to learn as they experienced personal and professional needs that require new knowledge to help them face real problems of daily life, aiming for immediate application in emergency situations ${ }^{(12-13)}$.

In order to do so, virtual simulation also represents an important opportunity for the participant to take an active role in the development of concrete competences in a virtual environment and immediately verify the results of actions, as well as providing learning contexts, which take place in the convergence of education and caring in nursing ${ }^{(17)}$. The virtual simulation from clinical cases enriches the teaching and learning process, providing scenarios closer to the real situation and allowing the participant to use prior knowledge for decision making and problem solving, 
transforming learning into meaningful experience ${ }^{(13)}$. It favors innovative teaching by allowing the development of competencies and, provides autonomy in the decision-making of adult participants, and has peculiar characteristics, such as different rhythms and styles of learning that should be considered in the development of training programs online.

Adults are motivated to learn according to personal and professional needs and interests of new knowledge that contribute to independence, self-management and immediate application in coping with real daily problems ${ }^{(12)}$. Online education, through virtual learning environments, favors self-directed and self-determined learning, valuing prior knowledge, and allows the participant to establish the path to be covered $^{(12-13,17)}$, therefore, the criteria for selection of content and teaching materials should be more challenging, so that the participant can learn and verify what has been learned.

Thus, the design of the online course, guided by the principles of Andragogy and Significant Learning Theory, allied to the new educational technologies, seeks to take advantage of previous experiences as anchors for knowledge construction, in a self-instructional way and at a distance. It gives new meaning to learning, as well as enhancing autonomy, re-elaboration of concepts and acquisition of competences ${ }^{(13,18)}$.

The online course also proposed professional-centered education, making it the subject of the learning process. In addition, it allows the identification of knowledge gaps on the subject and favors the design of the study plan that meets the needs and can carry out when, where and how you want. In adult education, Andragogy is widely used as a learning resource in nursing, both in vocational training and in continuing education ${ }^{(18)}$.

Technological resources, such as games, videos, exercises and links, allow the participant to learn independently, privileging interactive teaching strategies and freedom to learn, according to their own rhythm and style of learning ${ }^{(5)}$. The creation of storyboards favored the communication between the production teams and the researcher, and allowed the organization of the contents, optimizing time and development costs. As digital technological resources, learning objects have some characteristics that favor the use, mainly in the educational area, such as flexibility, reusability, updating, interoperability and portability ${ }^{(5)}$, and can be made available through hyperlinks in virtual learning environment.

Resources in the format interactive exercises, games and simulation also help in the construction of knowledge and self-confidence, in a dynamic and fun way, and stimulates the participant to be the protagonist of the learning itself to face emergency situations ${ }^{(19)}$. Digital educational games propose interaction and challenges, collaborate with the development of participants, allow better accessibility, contextualization and learning, integration of concepts from the topic addressed with the real world, stimulate problem solving and logical reasoning and can be used as objects educational processes in training and evaluation $^{(19)}$.

Regarding the evaluation of the online course, aspects regarding the content were evaluated, considering it clear, concise, logical, pertinent, with high scientific technical rigor, with adequate vocabulary and appropriate complementary material, as well as updated references to favor the presentation of the content, the contextualization of the theme and the learning. In the evaluation of the virtual environment, it is considered that the simple and intuitive interface, with presentation of didactic material with icons, windows, images, animations and videos facilitates the navigation and the use by the participant, favoring the quick recognition of the functions and location of the information, preventing visual overload, making the environment more pleasant and attractive ${ }^{(8)}$. The careful production of these resources, considering the imagery subsidies, becomes essential to enhance le$\operatorname{arning}^{(20)}$.

The development of didactic scenarios requires fluency and digital expertise. Technological skills related to new forms of content creation and course 
management contribute to the development of digital construction strategies in nursing education. In the scope of Nursing, the development of technological research aims at the development of necessary competences, in the professional training and performance of nurses ${ }^{(4,17)}$. It is important to emphasize the importance of investments in new teaching modalities in this approach, such as self-learning, through videos and/or computer modules, as opportunities to train health professionals, with a reduction of cost and necessary resources $^{(6)}$.

\section{Conclusion}

The positive evaluation of specialists accredits the online course on advanced life support in adult cardiorespiratory arrest as a valid resource, capable of integrating innovative educational technologies and strategies to nurses for care in cardiopulmonary resuscitation.

\section{Collaborations}

Tomazini EAS, Tobase L, Teodoro SV, Almeida DM and Alavarce DC contributed with the design and structuring of the project, essay writing and critical review of the intellectual content. Peres HHC collaborated with the final approval of the version to be published.

\section{References}

1. Miccas FL, Batista SHSS. Permanent education in health: a review. Rev Saúde Pública. 2014; 48(1):170-85. doi: http://dx.doi.org/10.1590/ S0034-8910.2014048004498

2. Lahti $M$, Hätönen $H$, Välimäki $M$. Impact of e-learning on nurses' and student nurses knowledge, skills, and satisfaction: a systematic review and meta-analysis. Int J Nurs Stud. 2014; 51(1):136-49. doi: http://dx.doi.org/10.1016/j. ijnurstu.2012.12.017
3. Huang TC, Chen CC, Chou YW. Animating ecoeducation: to see, feel, and discover in an augmented reality-based experiential learning environment. Comput Educ. 2016; 96:72-82. doi: https://doi.org/10.1016/j.compedu.2016.02.008

4. Salvador PTCO, Rodrigues CCFM, Lima KYN, Alves KYA, Santos VEP. Use and development of teaching technologies presented in nursing research. Rev Rene. 2015; 16(3):442-50. doi: http://dx.doi. org/10.15253/2175-6783.2015000300018

5. Tamashiro LMC, Peres HHC. Development and assessment of learning objects about intramuscular medication administration. Rev Latino-Am Enfermagem. 2014; 22(5):716-23. doi: http://dx.doi. org/10.1590/0104-1169.3647.2472

6. American Heart Association. Highlights of the 2015 American Heart Association Guidelines Update for CPR and ECC. AHA [Internet]. 2015 [cited 2017 Feb 18]. Available from: https://eccguidelines. heart.org/wp-content/uploads/2015/10/2015AHA-Guidelines-Highlights-English.pdf

7. Silva AC, Bernardes A, Évora YDM, Dalri MCB, Silva AR, Sampaio CSJC. Development of a virtual learning environment for cardiorespiratory arrest training. Rev Esc Enferm USP. 2016; 50(6):98895. doi: http://dx.doi.org/10.1590/S0080623420160000700016

8. Landeiro MJS, Peres HHC, Martins TV. Construction and evaluation of interactive educational technology for family members acting as caregivers on caring for dependent people. Rev Eletr Enf. 2017; 19:a13. doi: http://dx.doi.org/10.5216/ ree.v19.38115

9. Filatro A, Cairo S. Produção de conteúdos educacionais. São Paulo: Saraiva; 2015.

10. Gonzalez MM, Timerman S, Gianotto-Oliveira R, Polastri TF, Canesin MF, Schimidt A, et al. I Diretriz de Ressuscitação Cardiopulmonar e Cuidados Cardiovasculares de Emergência da Sociedade Brasileira de Cardiologia. Arq Bras Cardiol [Internet]. 2013 [citado 2018 jul. 15]. Disponível em: http:// www.scielo.br/pdf/abc/v101n2s3/v101n2s3.pdf

11. Chatterjee D, Corral J. How to write well-defined learning objectives. J Educ Perioper Med [Internet]. 2017 [cited 2018 July 14]; 19(4): E610. Available from: https://www.ncbi.nlm.nih.gov/ pmc/articles/PMC5944406/pdf/i2333-0406-194-1a.pdf 
12. Leigh $\mathrm{K}$, Whitted $\mathrm{K}$, Hamilton $\mathrm{B}$. Integration of andragogy into preceptorship. J Adult Educ [Internet]. 2015 [cited 2018 July 28];44(1):9-17. Avaible from: https://files.eric.ed.gov/fulltext/ EJ1072924.pdf

13. Sousa ATO, Formiga NS, Oliveira SHS, Costa MML, Soares MJGO. Using the theory of meaningful learning in nursing education. Rev Bras Enferm. 2015; 68(4):713-22. doi: http://dx.doi. org/10.1590/0034-7167.2015680420i

14. Associação Brasileira de Normas Técnicas. ABNT NBR ISO/IEC 14598-6:2004: engenharia de software: avaliação de produto. Parte 6: documentação de módulos de avaliação. Rio de Janeiro: ABNT; 2004.

15. Campos GHB, Martins I, Nunes BP. Instrumento para a avaliação da qualidade de objetos de aprendizagem [perspectiva do usuário]. Coordenação Central de Educação a Distância da Pontifícia Universidade Católica do Rio de Janeiro - CCEAD PUCRIO [Internet]. 2008 [citado 2018 jun. 20]. Versão 5.0. Disponível em: http://web.ccead.puc-rio.br/ condigital/portal/InstrAvaliacao.pdf

16. Bhanji F, Donoghue AJ, Wolff MS, Flores GE, Halamek LP, Berman JM et al. Part 14: Education: 2015 American Heart Association Guidelines Update for Cardiopulmonary Resuscitation and Emergency Cardiovascular Care. Circulation. 2015; 132(18):561-73. doi: https://doi.org/10.1161/ CIR.0000000000000268
17. Pereira MCA, Évora YDM, Camargo RAA, Souza Teixeira CR, Cruz ACA, Ciavatta H. Ambiente virtual de aprendizagem sobre gerenciamento de custos de curativos em úlceras por pressão. Rev Eletr Enferm. 2014; 16(2):321-9. doi: http:// dx.doi.org/10.5216/ree.v16i2.22161

18. Draganoc PB, Sanna MC. Avaliação das competências dos professores de enfermagem para facilitar a aprendizagem de adultos. Cogitare Enferm. 2015; 20(3):556-64. doi: http://dx.doi. org/10.5380/ce.v20i3.41104

19. Fleury A, Nakano D, Cordeiro JHD. Mapeamento da indústria brasileira e global de jogos digitais. GEDIGames; Núcleo de Política e Gestão Tecnológica. Universidade de São Paulo [Internet]. 2014 [citado 2018 mai. 02]. Disponível em: http://www. abragames.org/uploads/5/6/8/0/56805537/ mapeamento_da_industria_brasileira_e_global_ de_jogos_digitais.pd

20. Gaydeczka B. A importância da leitura de imagens no ensino. Educ Rev. 2013; 29(03):33544. doi: http://dx.doi.org/10.1590/S010246982013000300015 